\title{
The Dialogic Relationship Between Poems and Paintings and its Application to Literary Education in High School
}

\author{
La relación dialógica entre poemas y pinturas y su aplicación a la \\ educación literaria en la educación superior
}

\author{
La relació dialògica entre poemes i pintures i la seua aplicació a \\ l'educació literària a l'educació superior
}

\author{
Marianna Toutziaraki. Phd. Candidate at the National and Kapodistrian University \\ of Athens, Greece. mariannatout@gmail.com \\ https://orcid.org/0000-0002-8406-9077
}

\begin{abstract}
The purpose of this paper is to discuss the dialogic relationship between literary texts and paintings and the function of painting pictures in the teaching of literature in Secondary Education. The incorporation of paintings into literary education is founded on Bakhtin's principle of dialogism. The wider spirit of the theory of dialogism allows us to detach the literary text from the solitude of its autonomy, connecting it not only to other literary texts but also to other forms of art, which unfold within a particular historical and cultural context. One example of the dialogic relationship between literature and painting could be the dialogue between the poem 'We are just some... [battered guitars]' of the Greek poet Kostas Karyotakis and two paintings of the Austrian artist Egon Schiele, which was deployed in a teaching session for Greek eleventh graders. This sample teaching, thoroughly described in the paper, gave prominence to the dialogic relationship between the poem and the paintings, tracing their analogies on a thematic, stylistic and sociohistorical level. It also brought out the students' role as active participants in the dialogue between the poem and the paintings and as crucial agents of the meaning- making process. This empirical research has proved that the utilization of paint images can reignite students' interest in the ideas and expressive ways of poetry and, therefore, contribute effectively to the achievement of the aspirations of literary education. Moreover, it has shown that the analysis of painting pictures can be fully incorporated into the implementation framework of the current teaching methods of literature. Furthermore, the teaching venture has indicated that the parallel study of literary texts and paintings can establish fruitful interdisciplinary links between the distinct fields of literature and painting, and initiate students successfully into the fundamental principles of art in general.
\end{abstract}

Key words: poetry, painting, Karyotakis, Schiele, dialogism, interdisciplinarity

Resumen

El objetivo de este artículo es analizar la relación dialógica entre textos literarios y el arte visual, y la función de las artes visuales en la enseñanza de la literatura en la Educación Secundaria. La inclusión 
de cuadros en la educación literaria está fundada en el principio bajtiniano del dialoguismo. En su versión más amplia, la teoría dialógica nos permite separar el texto literario de la soledad de su autonomía conectándolo, no solo con otros textos literarios, sino también con otras formas de arte que se desarrollan en un contexto histórico y cultural particular. Un ejemplo de relación dialógica entre literatura y pintura podría ser el dialogo entre el poema 'Solo somos unas... [guitarras maltratadas]' del poeta griego Kostas Karyotakis y dos cuadros del pintor austriaco Egon Schiele, que se utilizaron en el desarrollo de una clase de undécimo grado de alumnos griegos. Esta muestra pedagógica, ampliamente descrita en el artículo, enfatizó la relación dialógica entre el poema y los cuadros, trazando analogías a nivel temático, estilístico y socio-histórico. También promovió la participación activa entre los estudiantes en el diálogo entre el poema y los cuadros, en el cual los estudiantes actuaron como agentes cruciales en el proceso de creación de significado. Esta investigación empírica demuestra que el uso del arte visual puede despertar el interés de los estudiantes hacia las ideas y la expresión poética y, por lo tanto, contribuir de forma eficiente a la adquisición de las competencias académicas de la educación literaria. Es más, demuestra que un análisis pictórico puede ser plenamente integrado en la implementación del marco teórico de las estrategias actuales de la educación literaria. Asimismo, la actividad docente indica que el estudio paralelo de textos literarios y arte visual puede establecer conexiones interdisciplinares fructíferas entre los diferentes campos de la literatura y el arte, e iniciar con éxito a los estudiantes en los principios del arte en general.

Palabras clave: Poesía, pintura, Karyotakis, Schiele, dialoguismo, interdisciplinariedad.

\section{Resum}

L'objectiu d'aquest article és analitzar la relació dialògica entre textos literaris i l'art visual i la funció de les arts visuals en l'ensenyament de la literatura a l'Educació Secundària. La inclusió de quadre en l'educació literària està fundada en el principi bakhtinià del dialoguisme. En la seua versió més àmplia, la teoria dialògica ens permet separar el text literari de la soledat de la seua autonomia connectant-lo, no sols amb d'altres textos literaris, sinó també amb d'altres formes d'art que es desenvolupen en un context històric i cultural particular. Un exemple de relació dialògica entre literatura i pintura podria ser el diàleg entre el poema "Només som unes...[battered guitars]" del poeta grec Kostas Karyotakis i dos quadres del pinto austríac Egon Schiele que s'utilitzaren en el desenvolupament d'una classe d'onzé grau d'alumnes grecs. Aquesta mostra pedagògica, àmpliament descrita a l'article, va emfatitzar la relació dialògica entre el poema i els quadres tot traçant analogies a nivell temàtic, estilístic i sociohistòric. També va promoure la participació activa entre els estudiants en el diàleg entre el poema i els quadres en el qual els estudiants van actuar com a agents crucials en el procés de creació de significat. Aquesta investigació empírica demostra que l'ús de l'art visual pot despertar l'interés dels estudiants cap a les idees i l'expressió poètica i, per tant, contribuir de forma eficient a l'adquisició de les competències acadèmiques de l'educació literària. És més, demostra que una anàlisi pictòrica pot ser plenament integrada en la implementació del marc teòric de les estratègies actuals de l'educació literària. Així mateix, l'activitat docent indica que l'estudi paral-lel de textos literaris i art visual pot establir connexions interdisciplinars fructíferes entre els diferents camps de la literatura i l'art i iniciar amb èxit els estudiants en els principis de l'art en general.

Paraules clau: Poesia, pintura, Karyotakis, Schiele, dialoguismo, interdisciplinarietat. 


\section{Introduction}

The analogies between poetry and painting have been identified since ancient times. Simonides of Ceos used to say, as Plutarch informs us, that a painting

The paper focuses on the potential interpretative value of paintings for the didactics of literature, rather than on their decorative function as presented in the school books is a silent poetry and poetry is a painting which speaks (Aggelatos, 2017). Is it acceptable, though, to claim that these two forms of artistic expression, which make use of entirely different semiotic codes, can actually 'discourse' with each other? This paper aims, firstly, to search for the theoretical grounds on which this dialogic relationship could be founded. Moreover, it shows ways in which the dialogic connection between poetry and painting could be deployed in the teaching of literature in High School (Kalogirou, 2012). More specifically, the paper focuses on the potential interpretative value of paintings for the didactics of literature, rather than on their decorative function as presented in the school books. Furthermore, it seeks ways to incorporate harmoniously the use of painting pictures into the current teaching methods of literature. The possible outcomes of such an integration are sought through empirical research in a secondary school, in which images of Egon Schiele's paintings were utilized in the hermeneutic approach of Kostas Karyotakis' poem 'We are just some...'. Bakhtin's principle of dialogism laid the theoretical foundation for this teaching endeavor, which is an attempt to create interdisciplinary links between literature and painting.

\section{Bakhtin's principle of dialogism in language and literature}

Mikhail Bakhtin (1895-1975) is considered one of the greatest thinkers of the $20^{\text {th }}$ century. His ideas had a defining impact in many different fields of human thought: philosophy of language, ontology, aesthetics, literary theory, anthropology of literature, psychology, as well as social theory. Bakhtin's philosophical approach constitutes a theory of knowledge which attempts to understand human behaviour through the use of language. Its particularity, however, in relation to other theories, is the dialogic conception of language. Language is treated not as a closed system of signs but as communication. This concept of dialogue makes up the connective tissue which runs across his multifaceted work (Holquist, 2014).

According to Bakhtin, language is dialogic, as dialogic as life is by its very nature. Humans are engaged in an endless dialogue with their environment and they need to be responsive to others. Bakhtin (1981) considers that every word is an answer to something that was said before, and it simultaneously orients itself towards a future answer: 
The word in living conversation is directly, blatantly, oriented toward a future answer-word: it provokes an answer, anticipates it and structures itself in the answer's direction. Forming itself in an atmosphere of the already spoken, the word is at the same time determined by that which has not yet been said but which is needed and in fact anticipated by the answering word. (p. 280)

According to Bakhtin, all meanings must be searched for in such a dialogue. However, the meaning is born out of the dialogic meeting of two subjects, who use words which do not entirely belong to them. They belong to others, who, within their specific social context and in the passage of time, have charged words with particular meanings and intentions. Bakhtin (1981) claims that from the mouths of other people we take our words and make them 'our own':

Language is not a neutral medium that passes freely and easily into the private property of the speaker's intentions; it is populated -overpopulated with the intentions of others ... As a living, socio-ideological concrete thing, as heteroglot opinion, language, for the individual consciousness, lies on the borderline between oneself and the other ... The word in language is half someone else's. It becomes 'one's own' only when the speaker populates it with his own intentions, his own accent, when he appropriates the word, adapting it to his own semantic and expressive intention. (p. 294)

Closely related to the statement above is Bakhtin's concept of speech as polyphonic. Human speech incorporates several voices, which confer and even fight to prevail. The Greek author Yiannis Kiourtsakis (2016) conveys in the most eloquent manner the polyphony which he recognised in his own writing:

As I worked, I could hear more and more distinctly, behind my apparently monological writing, the most varied voices: the voices of dead friends or beloved authors, the voices of teachers, voices of many people who I met in my path and even more who I never met, as they have been digested in the collective voice of my language and, beyond that, in the collective voice of all the works, the languages and cultures which, consciously or unconsciously, have nurtured my voice. And today with surprise I discover that, from the first line of my trilogy to the last, the inner voice that comes from it, is constantly addressed, in secret or in plain way, to someone else, who has departed or who will arrive, for example the reader, of whom it persistently requests their participation, the answer which will make complete whatever meaning I transfused into every word of mine. (p. 113, my translation) 
Therefore, the search for meaning in dialogue is crucial not only for our oral communication but for literature as well. The literary text converses with texts that came before it and that will come after, in an endless chain of meanings. According to Bakhtin (1984), literary texts, as identical to the dialogue, intend for an answer to other texts, agreeing or disagreeing on commonly raised

The literary text converses with texts that came before it and that will come after, in an endless chain of meanings issues. Wertsch and Smolka (1994) note that the other texts are ever present, either referred to or silently presupposed. Also, the literary text engages in a dialogue with the reader, who is not regarded as a passive receiver of meanings exclusively enclosed within it but as an active participant- as Kiourtsakis highlights-in the completion of the meaning. Finally, the literary text discourses with the historical and cultural circumstance and tradition, through which it was born. Unlike formalistic approaches, which proclaim the autonomy of the literary text from its time and place, the concept of dialogism calls upon us to consider that the literary text responds dialogically to its historical and cultural background.

The dialogic character of literary texts has opened new prospects for the teaching of literature. According to Frydaki (2003), dialogism has allowed the teaching practice to relieve the literary text of the loneliness of its autonomy and integrate it in a wider circle of texts with which it converses within a common historical and cultural context. The literary texts which are coexamined in class may not discourse in the strict terms of intertextuality (Kristeva, 1969, 1980), meaning that certain elements -intertexts-, which make their dialogic connection apparent, may not be found in them. However, these texts could engage in discourse with each other in accordance with the broader sense of Bakhtin's theory of dialogism.

\section{The dialogic relationship between literature and painting: The case of Karyotakis and Schiele}

The concept of dialogism does not have to be restricted to the relationship between literary texts. The wider spirit of Bakhtin's theory of dialogism allows us to detach the literary creation from the restraints of its autonomy, connecting it not only to other literary texts but also to other forms of art, which unfold within a particular historical and cultural context. Besides, as Bakhtin notes (1984), literature, as language itself, is an integral part of culture and it is impossible to be understood outside the cultural frames of a certain age. These cultural frames also include the fine arts, such as painting, which could be taken into consideration, so that literature is perceived. Therefore, literary texts and paintings could discourse with each other, 
expressing converging or diverging positions, within a shared historical and cultural background, their only difference being the different semiotic codes.

The wider spirit of
Bakhtin's theory of
dialogism allows us to
detach the literary
creation from the
restraints of its
autonomy, connecting it
not only to other literary
texts but also to other
forms of art, which unfold
within a particular
historical and cultural
context.

The wider spirit of Bakhtin's theory of dialogism allows us to detach the literary creation from the

One such example is the dialogic relationship between Kostas Karyotakis' poem 'We are just some...' and Egon Schiele's artworks, which will be highlighted later on in this paper through the description of a teaching session in Senior High School. Both the poem and the paintings seem to raise a common topic, in tandem providing answers to the question 'who are we as poets and as artists in the historical and cultural context of the first decades of the 20th century'. We cannot claim that the Greek poet and the Austrian painter engage in an actual dialogue with each other, since it is neither the case that the paintings are a depiction or an illustration of the text, nor is the poem a description of or an allusion to the visual images. Also, we cannot know if the poet and the painter were aware of each other's existence and work. Even though they were both born in the last decade of the 19th century and the prime of their youth coincided with the first decades of the 20th, they lived in different countries. Karyotakis (1896-1928) lived in Greece, while Schiele (1890-1918) lived in Austria.

However, we could speculate that both Karyotakis and Schiele were influenced by the same European poets and painters who lived and worked in the latter half of the $19^{\text {th }}$ century and the beginning of the $20^{\text {th }}$. Karyotakis made plenty of journeys abroad and his translated poems of Heine, Baudelaire, Verlaine and Corbiere, included in his two large collections of poems, 'Nepenthe'11 (1921) and 'Elegies and Satires' (1927), imply his relationship with the European poetry. Following Bakthin's concept of dialogism and extending it to the dialogic relationship between literature and painting, we could argue that Karyotakis' poetic language could have been 'populated with the intentions' not only of other poets but also painters. It is possible that Karyotakis' poetic images have been influenced by the visual images created by the same painters who influenced Schiele's artistic work too. Extending Bakhtin's quote to the dialogic connection between literature and painting, we could claim that both Karyotakis' poem and Schiele's paintings were responses to either literary texts or artworks created before them and

\footnotetext{
${ }^{1}$ The word "nepenthe", plural of nepenthes, comes from the fourth book of The Odyssey. It means a medicine (pharmakon), which calms the enraged and gives oblivion of all evil.
} 
that they oriented themselves towards future literary or artistic answers: 'forming' themselves 'in an atmosphere of the already spoken' or depicted artistically- as we could add-, and the same time 'determined by that which has not yet been said' or presented visually, 'but which is needed and in fact anticipated by the answering word' or image, Karyotakis' poem and Schiele's paintings could be parts of an endless chain of indirect dialogues.

Therefore, Karyotakis' poetic text and Schiele's artworks could correlate and be studied together. As it will be clarified through the description of the teaching session that will follow, their dialogic relationship lies on the following axes:

a) The axis of topic or pattern: Karyotakis' poem and Schiele's paintings share patterns and deal with the same topic, namely, the psychological disintegration of artists.

b) Sociohistorical axis: The poem and the paintings express their creators' emotions, ideas, attitudes and perspectives within the same era and within a similar or shared historical and cultural context, including World War I.

c) The axis of artistic style: Both the poem and the paintings exceed traditional means of expression and move bravely into the distortion of the form, which characterizes the modernistic movement of art.

The wider analogies, which can be noticed in the thematic interests, the artistic style and the life experiences of the two creators also lay the foundations for the parallel study of their works. First and foremost, there is an analogy in their themes and the mental disposition they express through their works. Neither Karyotakis nor Schiele draw their topics on the joyful and peaceful aspects of life. Karyotakis' body of work is defined by an intense pessimism, which has seldom been expressed in modern Greek poetry so tragically and honestly. The poet reveals the most dishonorable, vile, and rotten aspects of his time. He writes poems for 'the unknown Poets of the Ages', 'Government clerks' and 'Salaried job', 'Loneliness', 'Dying', 'Decay', even for 'Imagined Suicides'. He also wrote a poem for the genital disease, by which he was affected, named 'Spirochaeta Pallida'. Karyotakis' desperation often becomes a cry of protest reaching the realm of irony and sarcasm. Schiele, quite similarly, manifests a creative obsession with the themes of death, illness and isolation. The titles of some of his works are indicative of his thematic interests: 'Death and Maiden', 'Dead Mother I', 'Mourning Woman', 'Sick Girl Seated', 'Hermits'. His figures, as well as his self-portraits, exude the sentiment of withdrawal, loneliness, nervousness, despair and decay. He is, also, very fond of painting nudes in sexually exposing, strange poses, which combine an erotic allure with a sense of aversion (Arnason, 2006). The 
painter is in no case concerned with the representation of beauty and harmony; instead, what he highlights most is ugliness and disharmony.

The themes and the mental disposition expressed in Karyotakis' poetry and Schiele's painting were possibly defined by the historical and social experiences of their lives. First and foremost, they both experienced the tragedy of the First World War. Moreover, both were persecuted and

The themes and the mental disposition expressed in Karyotakis' poetry and Schiele's painting were possibly defined by the historical and social experiences of their lives. First and foremost, they both experienced the tragedy of the First World War. Moreover, both were persecuted and censored for their social nonconformity and their tendency to dispraise the corrupted civil values of their times. censored for their social nonconformity and their tendency to dispraise the corrupted civil values of their times. On one hand, Schiele's drawings were confiscated by the police in 1912, as they were considered pornographic, and in court the judge burnt one of the offensive drawings over a candle flame (Egon Schiele: The Complete Works, n.d.). These drawings, though, are thought to be the unconventional painter's effort to expose the hypocrisy of the Viennesse bourgeois society, which prudishly concealed its appealing sexual practices (Dabrowski, 1997). On the other hand, the satirical magazine which Karyotakis published, 'The Calf', in order to denounce the denervated ideas of the Greek society, was outlawed in 1919 (Savvidis, Hatzidaki \& Mitsou, 1989). The poet, who was also a graduate of Law School and a civil servant, was punished by the state for his 'insubordination of ideas' with unfavourable and demeaning transfers to provincial towns around Greece (Vournas, 1988, p. 831).

Another analogy between the poet and the painter, which may have had a significant impact on their work, is that disease shadowed intensely their personal lives. More specifically, three of Schiele's siblings had died before he was born and the fourth one when he was three years old. These deaths were the tragic outcome of his father's venereal disease, syphilis, by which he had been infected in his youth. When Schiele was fourteen, his father having already succumbed to insanity, died (Dabrowski, 1997). Karyotakis himself suffered from syphilis, which was then an incurable disease as well as a tremendous social stigma. It is also unfortunate that both the poet and the painter experienced a premature death. In 1918, at the end of World War I, Schiele passed away, aged only twenty-eight, as a result of the Spanish flu pandemic, which had also claimed the life of his pregnant wife three days earlier. In 1928 Karyotakis, during his last transfer to a small provincial Greek town, Preveza, at the young age of only thirty-two, chose to put an end to his life by committing suicide. 
On a stylistic level, both the poet and the painter were influenced by the movement of modernism, which reached explosive dimensions in Western Europe at the beginning of the $20^{\text {th }}$ century. One of the main characteristics of modernism is the distortion of the traditional poetic and artistic form. Schiele, specifically, is considered as one of the greatest representatives of expressionism, one of the Avant- Garde movements which manifested themselves within the broader artistic movement of Modernism. As all expressionist painters, Schiele abandoned any attempt to simply reproduce the elements of reality; he did not hesitate to disfigure things, in order to express his personal feelings. As Dabrowski writes (1997), Schiele,

in the process of evolving his own original Expressionist style, ... introduced a crucial change, a different concept of beauty (or rather ugliness) in the form of expressive distortion. This distortion conveyed psychological states of mind and replaced the traditionally recognized ideal of beauty as embodied in the conventional academic renderings of the model. (p. 12)

Schiele's distinctive artistic style included grotesque depictions of an emaciated youth, contorted bodies, jagged and tension-revealing lines and unusual combinations of colours. Leopold (1997, p. 32), though, praising the uniqueness of Schiele's work in the art of his time, notes that Schiele is much different from other expressionists and 'explored such a wide variety of styles, that he cannot properly be identified with any particular movement or school'.

The difficulty of categorizing Karyotakis' work into a specific genre of poetry is even greater. This difficulty is informed by numerous critical studies, in which he is considered either as a postromantic and an heir to the symbolists or as a modernist and a precursor of the postmodern (Reader \& Taylor, 2006). Though Karyotakis didn't reach the levels of the distortion of the poetic form which characterizes the work of sequent modernist- mainly surrealist- Greek poets, his significant connection to modernism has been highlighted by many researchers. Paganos argues that 'after Karyotakis, modernism finds the doors of Greek poetry burglarized' (2003, p. 100, my trans/ation). More specifically, critics point out the innovative traits of his poetry, such as the anti-poetic and prosaic words which he employed or the rupture of the rhythm, 'always', though, 'in a normal metric system, which is disfigured but not cancelled out'. (Peri, 1990, p. 100, my translation) Agras (1981) notes that

his poems are fashioned in stanzas which appear of the regular type, having equal verses between them, and rhymes. However, if we look a little more closely, such freedom, such untidiness, such anarchy! He may not have written in vers libre, yet 
Karyotakis wrote in vers liberé, with liberties no one had dared in Greek poetry. (p.

217, my translation)

Indeed, the antinormative Karyotakis' pauses give his verse the feeling of an asthmatic breath, which entirely conveys his mental state. Let us take a closer look to his poem 'We are just some...' through the description of the teaching session that follows.

\section{Teaching session: The dialogic relationship between Kostas Karyotakis' poem and Egon Schiele's paintings}

The two-hour teaching session described below ran for a class of twenty Greek eleventh graders, aged seventeen. The class consisted of both competent and struggling readers. The students, with the guidance of the instructor and author of this article, delved into Karyotakis' poem 'We are just some... [battered guitars]'. This poem belongs to the poet's last collection, 'Elegies and Satires', published in 1927. The students approached the original Greek version of the poem in their school textbooks. The English translation, edited by William W. Reader and Keith Taylor (Kostas Karyotakis, 2006, p. 103), is also presented below:

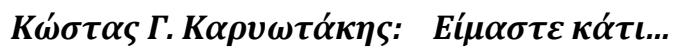

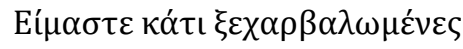

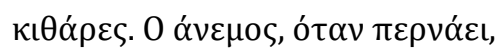

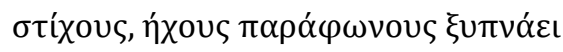

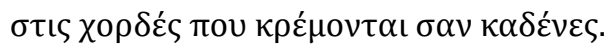

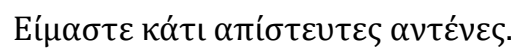

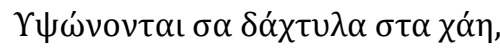

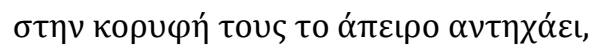

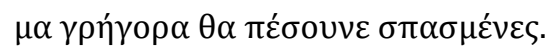

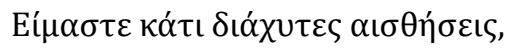

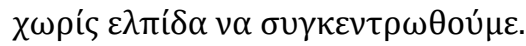

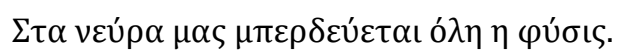

Kostas G. Karyotakis: We are just some...

We are just some battered guitars.

When the wind blows over us,

it awakens verses and dissonant sounds

on strings that droop like watch chains.

We are just some unreliable antennae

that stick up like fingers in the void;

infinity resonates at their tips,

but they'll quickly collapse, shattered.

We are just some diffused sensations

without hope of getting focussed.

All nature is entangled in our nerves. 


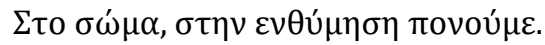

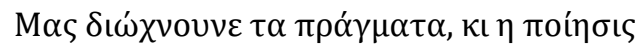

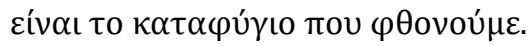

We suffer in body and in our memory.

The things of the world dismiss us, and poetry is the refuge that we covet.

Teaching Objectives:

a) Help students understand the poet's psychological condition through the symbolic pictures he employs and connect it with the historical circumstances of his time.

b) Enable them to realize the modernistic traits in Karyotakis' poetry and connect them to modernistic features in Schiele's paintings.

c) Encourage them to be concerned with the potential of the literary and the artistic code when it comes to expressing mental states and compare them.

d) Get them involved in the dialogue between the poem and the artworks and experientially express 'who they are' within their generation or time.

The teaching method which was implemented, in order for the above objectives to be achieved, was mainly hermeneutics, with the employment of the hermeneutic circle (whole-parts-whole), which supported the cohesion of the poem. More specifically, the comprehension of the whole occurred through the processing of its parts and, in turn, the parts were understood through the conception of the whole. The unity of the poetic, as well as the artistic, work was preserved by the parallel study of its content and form (Spanos, 2002). The instructor's explicit questions guided the students to move from their initial, intuitive responses to the examined works towards a close reading analytical process (stages 3.2. and 3.3.). As stated above, the teaching endeavor was founded on Bakhtin's principle of dialogism. It gave prominence to the dialogue between Karytotakis' poem and Schiele's paintings (stage 3.4.), as well as the dialogue between the students and the aforementioned works, which ran across the whole teaching process and reached its peak in stage 3.5. The method of guided discussion prevailed in this teaching session, with students being active participants in the dialogue between the works,
The teaching method which was implemented, in order for the above objectives to be achieved, was mainly hermeneutics, with the employment of the hermeneutic circle (whole-parts-whole), which supported the cohesion of the poem. 
and crucial agents of the interpretation of the poem. The session is described in the following stages:

\section{The students' initial response to the whole poem}

\subsection{The analysis of the poem}

The instructor read the poem out and, then, she urged the students to express their first impression, asking them 'What sense did the poem leave you with in its totality?' The students' answers highlighted the sense of disorganization, dissolution and desperation that the poem exudes.

With the proper guidance, the instructor invited the students to a closer reading of the text. Initially, by asking them 'Who is feeling this desperation?', she drew their attention to the first person in the plural form ('We are'). The students noticed that the sense of disorganization and dissolution does not concern only the poet himself but also a broader group of people. In the question that followed, 'Which group does the poet represent? Who 'are we'?', some students based their answers on the last verses ('poetry is the refuge that we covet'), assuming that Karyotakis refers to poets. The instructor invited the students to observe the predicate nouns that follow the linking verb 'to be' ('guitars', 'antennae', 'sensations'), as well as all the nouns that attribute qualities to the subject ' $w e$ '. The students observed that the nouns refer to a world of art ('guitars', 'poetry', 'verses', 'sounds'), to a world of observation and sensitivity ('sensations') and to a world of receptiveness to messages from the external environment ('antennae'). They concluded that the people behind 'we' are the poets, and possibly all artists as well, who display sensitivity and alertness before the stimuli they receive with their 'antennae'.

To the question 'What mental state are these poets in?' the students repeated their initial answers with regards to the sense of dissolution. By asking 'How does the poet manage to create this sense?', the instructor invited them to connect their replies to the specific verbal elements of the text. The students commented on the words and phrases which triggered the sense of dissolution ('battered guitars', 'strings that droop', 'collapse, shattered'), the impossibility of the artistic expression ('verses and dissonant sounds'), the difficulty in concentration ('diffused sensations/ without hope of getting focused'), the nerve confusion ('All nature is entangled in our nerves') and the psychological pain, which is so acute that it is presented as physical too ('We suffer in body and in our memory'). 
'Why do poets experience this psychological dissolution? Is there some indication in the text about the cause that makes them suffer?' The students focused on the verses 'The things of the world dismiss us' and 'We suffer in... our memory', implying that reality puts them off and that something, which happened in the past, deeply hurts them. The context of the poem triggered the interpretive process, as the students were reminded of the tragic historic events that Karyotakis' generation experienced in Greece, with an emphasis on the defeat in Asia Minor in 1922 and the following brutal exchange of populations. 'Is there any hope whatsoever for the poets to rise above this situation?' The students referred to the verses 'poetry is the refuge that we covet' and commented that the poets' situation is presented as a dead-end. Poetry is their sole refuge in a repulsive reality yet they end up coveting it. It is about an oxymoron which expresses the confrontational relationship of poets with their art.

The reason behind coveting cannot be clarified within the poem and so the students proceeded with certain interpretive assumptions: Firstly, poetry gives poets a psychological and spiritual uplift, which cannot be given by reality itself. Therefore, they end up coveting it, just because it is not palpable. Secondly, poets covet poetry, because it no more offers them what they crave for-solace, hope for life, truth, pure visions- and, eventually, it cannot change the world. Thirdly, poetry discloses their own inability to express themselves poetically. Poets' psychological and mental state prevents them from expressing themselves perfectly. Therefore, poetry becomes an elusive refuge thereby evoking envy in them. The students, after having been called to evaluate the adequacy of their above-mentioned assumptions, concluded that the last one is the most solidly founded on the text, as it is connected with the symbolic image of the "battered guitars'. Just like the guitars, which are musical instruments with great melodic potential but unfortunately 'battered' and rendered useless, the poets experience such a similar dissolution and as a result they cannot express themselves harmoniously; they produce 'verses dissonant' instead. 


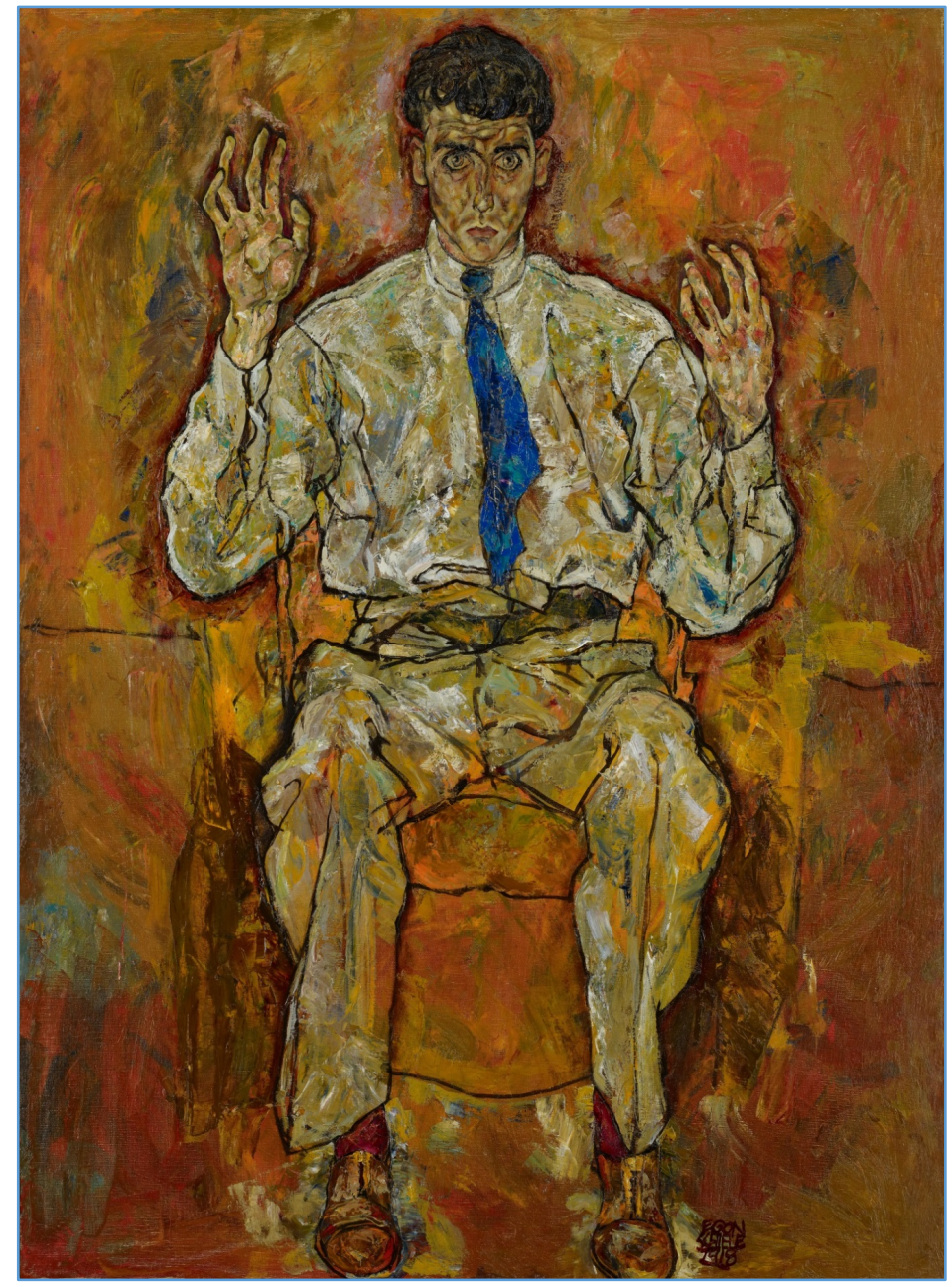

Figure 1. Portrait of Albert Paris von Gütersloh, 1918. Oil on canvas.

Minneapolis Institute of Arts, Minnesota, US 


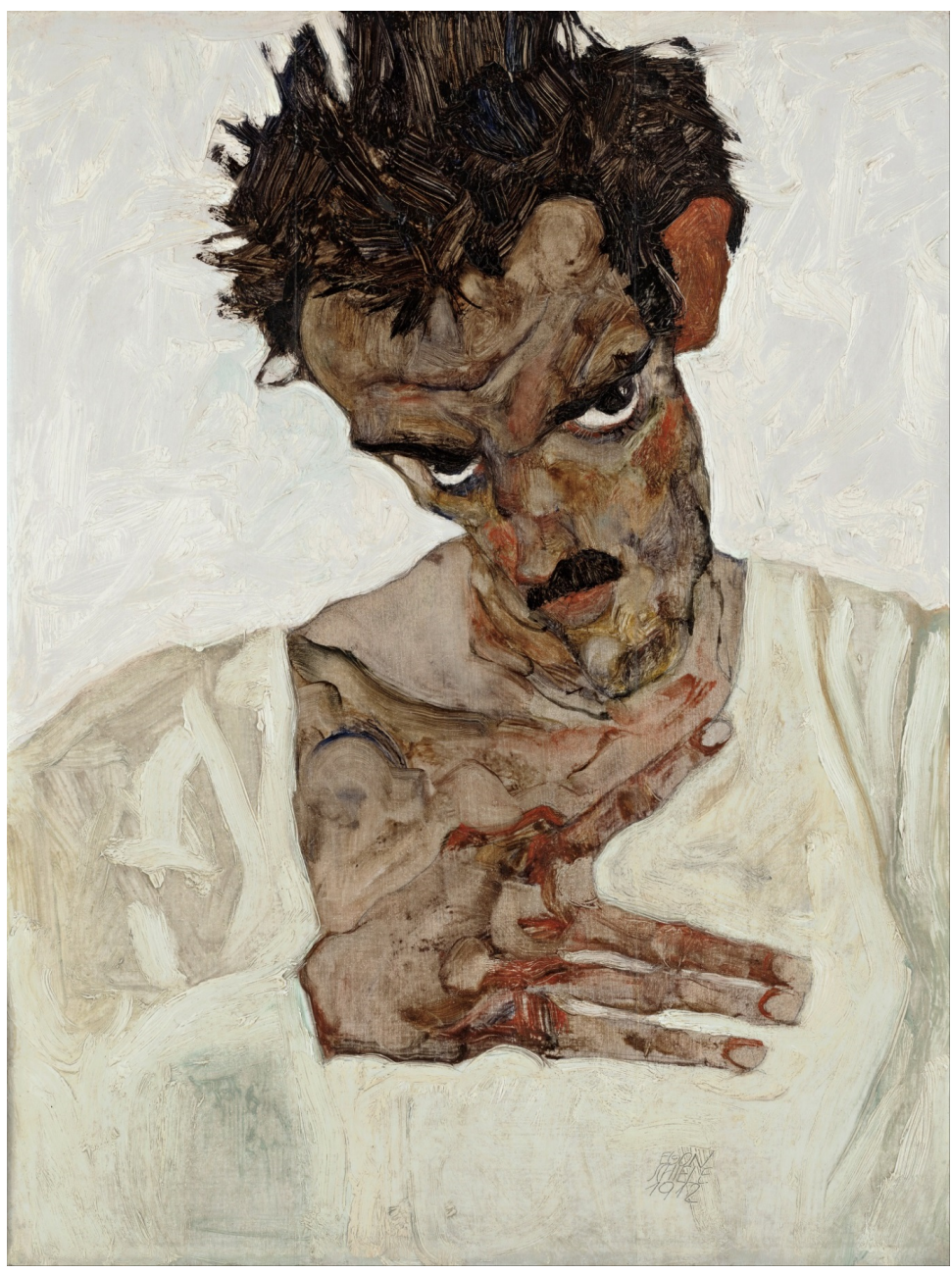

Figure 2. Self-Portrait with Lowered Head, 1912. Oil on Wood. Leopold Museum, Vienna, Austria

\subsection{The presentation and the analysis of the painting pictures}

The instructor informed the students that in Karyotakis' time there lived a great Austrian expressionist painter, Egon Schiele, and introduced them to the pictures of his artworks. Just like in his poem Karyotakis expresses his own psychological and mental state as well as that of his fellow poets, so does Schiele in his paintings; he expresses his own psychological and mental state and that of his fellow-craftsmen as well, that is, the painters. More specifically, the second painting (Image 2) is a self-portrait of the painter; it expresses, the way Schiele saw himself. The first painting (Image 1) is the portrait of an Austrian painter and poet, Albert Paris Gütersloh, and obviously depicts the way Schiele viewed another artist from his circle.

The instructor asked the students to say what their initial perception of Image 1 was. The students answered that the painting radiates nervousness and intensity. The instructor invited them to ponder on the elements of Schiele's artistic code -composition, colours, lines and contours- which gave them this impression. The dialogue that followed made the following 
points stand out (the words in italics were written on the blackboard): The intense nervousness

is caused by placing the artist's silhouette on the central axis of the work composition; he himself, actually, is rigidly seated, unnaturally still, looking straight and strictly in our direction with his eyes wide open and his forehead flinching. The intense nervousness of the artwork is enhanced by the colour disharmony in the background, as warm colours (red, yellow) and cool ones (green) blend, strive to prevail and diffuse the man's garments and skin, as well as the black intersecting lines on the clothes, indicating imbalance and confrontation.

Then the instructor tried to bring out the students' primary response to Image 2 . They observed that Schiele's self-portait is frightening and grotesque and were called upon to seek how the painter causes this horror. The students commented that the man depicted is hideously defaced. On his face, which is leaning downwards, only his eyes move upwards looking straight, quite inconveniently, at the viewer. His gaze seems violent and expresses psychological intensity and disorder. The contrast between the white of the eyeball and his dark face increases the intensity of his gaze. On his face, as well as all over his flesh, the tones of brown, green, yellow and red prevail. These unnatural colours, which have been spread untidily and come into contrast with the white background, express a terrible physical decline giving the impression that the figure is undergoing a state of decay. The lines are shaky and sinuous and create a nightmarishly bony and disfigured human body.

\subsection{The dialogue between the poem and the paintings}

\subsubsection{The dialogue on a thematic level}

The instructor, intending to bring out the thematic analogies between the poem and the artworks, asked: 'Is there something in common in the way Karyotakis and Schiele view themselves and their group of fellow-craftsmen, namely the poets and the painters?' The students observed that both Karyotakis and Schiele convey the sense of intense nervousness and psychological dissolution of the artists, as well as their inability to express themselves beautifully. Schiele's self-portait, however, expresses a neurotic and psychological disorder in a much more graphic and horrific way than Karyotakis' poem.

In an effort to search for more specific common poetic and visual patterns, the instructor asked: 'Are there any elements in Schiele's paintings that remind you of a verse in Karyotakis' poem?' The majority of the students focused on the common pattern of fingers. The stretched fingers in Schiele's artworks brought to their mind the verses 'We are just some unreliable antennae/ that stick up like fingers in the void'. The fingers of the painter Albert Paris Gütersloh, are also 
raised, just like in the poem, as if suffering from ankylosis. They look like 'antennae', which receive neurotic signals from the surrounding background of electrified colours. We do not know whether 'they'll quickly collapse, shattered' for the time being they seem to have an aggressive mood. One palm is turned outwards, as if the painter wishes to attack and drown something outside himself, while the other one is turned inwards, as if intending to attack his own self. In Schiele's self-portait the fingers are presented even more aggressive. The students observed that his bony open fingers look like scissors that threaten to cut something. If the fingers of the depicted painters symbolize something similar to the poets' fragile 'antennae' in Karyotakis' verses, then perhaps their aggressive mood represents their very last and desperate attempt to be alert before a reality that leads them to collapse.

Moreover, the students pointed out the following analogies between the poem and the artworks:

- The colours which do not blend harmoniously in the background of Image 1 and in the painter's skin of Image 2 are 'dissonant' just like the 'verses and dissonant sounds' in Karyotakis' poem.

- The defaced look of the figure in the self-portrait reminded the students of the verse 'We suffer in body and in our memory', as it expresses a horrible physical and psychological distortion.

- The inner confrontation that Karyotakis voices about his art is also expressed in Schiele's works. Looking at his self-portrait, the students argued that that he could be saying 'painting is the refuge that we covet'. While he resorts to painting, in order to express himself, he ends up painting himself as a repulsive figure.

\subsubsection{The dialogue on a stylistic level}

Afterwards, the focus of the teaching shifted towards the analogies between Karyotakis' poetic style and Schiele's artistry. The students were called upon to search into the means of expression through which the poet and the painter convey their psychological dissolution.

The instructor had already written on the blackboard certain words that the students had mentioned while analysing Schiele's artworks, like 'disfigurement', 'expresses', 'colour disharmony', 'unnatural colours spread untidily', and 'intersecting, shaky, sinuous lines'. Analysing these words, she informs them that Schiele's disfigurement, that is, the distortion of the elements of reality, is a basic characteristic of the artistic movement of modernism. The 
special use of colours and lines contributes to this disfigurement. Disfigurement, actually, aims at the strongest possible expression. In other words, Schiele disfigures his face, in order to express his feelings more forcefully. A more realistic representation of himself and a more loyal compliance with the rules of traditional, academic painting could not have expressed his psychological dissolution more accurately. The Avant- Garde modernistic movement of expressionism, where Schiele belonged to, was named after the French word expression and was manifested in the first three decades of the $20^{\text {th }}$ century, with Germany being its hub.

Schiele's visual code, therefore, enabled him to express in this way his psychological state. 'What is the potential that the poetic code offers towards the same cause?' The instructor informed the students that, just like Schiele is considered to be one of the main representatives of expressionism-modernism in Europe, the same applies to Karyotakis, who is considered as a pioneer of modernistic poetry in Greece. The basic characteristic of modernistic poetry, as well as of painting, is the distortion of the form and the violation of the traditional rules of poetry: grammar, syntax, metre, rhythm, rhyme, punctuation marks, neat and fine diction.

The students, once again, were called upon to trace modernistic traits in Karyotakis' poem. Under the instructor's guidance, they noticed that the original Greek poem incorporates several characteristics of traditional poetry, since it has rhymes (in the English translation of the poem the verse is more free) and follows the conventions of the traditional sonnet, that is, it has four stanzas, two of which are four-versed and two three-versed. However, its anti-poetic words

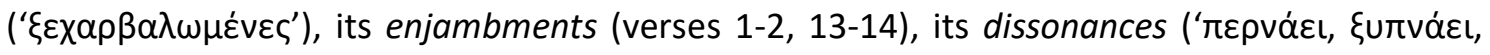
$\left.\alpha \vee \tau \eta \chi \alpha \varepsilon^{\prime}\right)$ and the rupture of the rhythm are modernistic traits that alienate the poem from the expressive perfection of traditional poetry. These traits, together with the strong symbolic pictures, emanate the sense of dissolution the poet wishes to express.

The words in italics had been written on the blackboard, where now there were two columns, one with the characteristics of modernism in Karyotakis' poem and another one with those in Schiele's paintings. In the final reading of these traits, what came out and was commented on was the parallel potential of the poetic and the visual code to express psychological states. It is worth noting that the co-examination of the lingual and the visual code seemed to reignite significantly the students' interest in the analysis of the form and the content of the poem. Quite surprisingly, even the students who usually exhibited increased difficulty or indifference during the typical lessons of poetry, in this teaching session participated more actively in the dialogue between the poem, the paintings and their classmates.

5.3.3 The dialogue on a sociohistorical level 
The distortion of the form expresses the dissolution of the soul. The latter, though, is inextricably interwoven with the historical and social framework within which the artists live, feel and express themselves. Besides, modern art manifests an absolute awareness of all the things that happen in the world where it is practiced (Faulkner, 2013). The students were called upon to search into the historical and social circumstances in which Karyotakis' poem and Schiele's paintings were created and contemplate possible reasons for the mental disposition they express within their works. The instructor wrote on the blackboard the dates of birth and the place of residence of the two creators and asked the students to guess possible analogies in their experiences: 'Kostas Karyotakis: 1896- 1928, Greece. Egon Schiele: 1890- 1918, Austria.'

The students observed that both creators died very young and lived a short life in about the same era, from the last decade of the 19th century till the first decades of the 20th. They concluded that the peak of the poet and the painter's youth coincided with the First World War (1914-1918). The instructor drew the students' attention to the dates in which Schiele's paintings were created: In two years after 1912 (Image 2) the Austro-Hungarian Empire declared the war on Serbia, giving rise to World War I, in which the disastrous imperialistic attitudes of the most powerful countries of that era were channeled. In 1918 (Image 1) the Austro-Hungarian Empire collapsed due to its defeat in the war and Schiele himself passed away, as a result of the Spanish flu pandemic, which claimed the lives of twenty million people.

The instructor highlighted 1927, the year in which Karyotakis' poem was publishedlt became evident that the poem was written in the first decade of the Mid war years (1920-1930). During the previous decade (1910-1920) Greece experienced successive national challenges, namely the Balkan Wars, the First World War and the beginning of the campaign in Asia Minor. Five years before the publication of the poem in 1922 Greece experienced the darkest page in its history, the tragedy of the Minor Asian catastrophe and the exchange of populations. In the years that followed, hundreds of thousands of Greek refugees, uprooted from their homeland, were crowded in Greece. The political, social and economic problems were thorny, while the plagues of the time, malaria and tuberculosis, decimated a high number of people. In 1928, a year after the publication of the poem, Karyotakis chose to put an end to his life. In his suicide note, translated into English by Reader \& Taylor (Kostas Karyotakis, 2006), the poet wrote, among others:

I' m paying for all those like myself who didn't have any ideal in their life, who always remained victims of their own indecisiveness, or who regarded their existence as a game without substance. I see them coming more and more with the passing of the 
centuries, treading on beliefs and simple superstitions. To them I address myself. (p.

xvii)

\subsection{The 'return' to the poem as a whole and the students' dialogue with their own sociohistorical context}

Karyotakis, through his poem, and even through his suicide note, addresses himself to us, his future readers. As Bakhtin would say, his words are oriented towards our answer. How do we respond to them? 'Who are we', as the residents of this world in the $21^{\text {st }}$ century? In this last stage of the teaching process, the students were asked to reread the poem and write their own version using the first half of Karyotakis' first verse ('We are just some...'), in correspondence to Bakhtin's quote (1981, p. 280) that 'the word in language is half someone else's'. They had to fill in the missing part of the verse in their notebooks using at least two more words and explain to their classmates the reasons behind their choices. This hands-on activity helped bring out the way through which the students conversed not only with Karyotakis' poem but also with their historical and cultural background. Some of the students' answers were the following:

- 'We are just some filtered images on a computer': promotion of a misleading image of ourselves through the social media.

- 'We are just some dead consciences on a sandy beach where drowned kids lie': the inability of the international politics to serve man regarding the war in Syria and the refugee influx.

- 'We are just some massive sleepwalkers of life': massification, lack of alertness and disorientation by the mass media.

\section{Conclusions}

As the empirical research described above manifested, the incorporation of paintings into the didactics of literature can offer a suitable field for the

The parallel didactic approach of literary texts and paintings does not degrade the linguistic function of the lesson; on the contrary, it seems to enhance it significantly implementation of Bakhtin's theory of dialogism. The parallel study of literary texts and paintings in class can create fruitful dialogic channels between the distinct fields of literature and painting. As it became apparent, the analysis of painting pictures can be integrated harmoniously into the current teaching methods of 
literature. It can functionally be incorporated into their implementation framework and effectively serve the lesson objectives.

Moreover, the practical experience of the above teaching session has proved that the functional utilization of paint images in the teaching of literature can lead to beneficial educative outcomes. The parallel didactic approach of literary texts and paintings does not degrade the linguistic function of the lesson; on the contrary, it seems to enhance it significantly. Compared to an average lesson of poetry, the co-examination of the poem and painting in this teaching session activated substantially the students' mood to speak, describe, express feelings, discourse with each other, exchange viewpoints and even express themselves through poetic discourse. This outcome can be attributed to the combination of the lingual and the visual code, which appeals to more senses and motivates the students' cognitive and emotional powers more keenly. Although it can be argued that poetry itself triggers the students' imagination, so that they can create their own mental images, the significant impact that actual paint images may have on the students' mental and emotional activation cannot be disregarded or downgraded.

It is worth noting that the use of painted pictures proved to be overly beneficial to the students who generally exhibit increased difficulty or indifference during the typical lessons of poetry in High School. For these struggling readers, who usually regard the linguistic poetic discourse as incomprehensible or even unapproachable, the images served as bridges of communication with its seemingly 'unreachable' linguistic code. The pictures of Schiele's paintings, unpleasant or even repulsive by sight, managed to spark these students' interest in the poem and to motivate their participation in the meaning- making process. Besides, modern students seem to have developed a great familiarity with visual images- albeit of a disputable quality- through their constant exposure to the mass media. If the instructors turned this to their own advantage, by offering students visual stimuli of a higher quality, like paintings, in the teaching of literature, the gain could be double: students' interest in literary texts could be renewed and their ability to appreciate the quality of visual images could be enhanced.

The pictures of paintings, however, are likely to be equally beneficial to the students who are competent readers and already enjoy the subject of literature in High School. In our teaching endeavor, the images seemed to have drastically stimulated students' interest in the topic, the style and the historical context of the poem. Several students stated that they deeply realized the modernistic expressive means of the poem as they compared them to the corresponding expressive means of the visual, and therefore more intuitive, visual code. Furthermore, the 
parallel study of the poetic text and the paintings seemed to have enriched these students' concern about the fundamental principles of art. It sharpened their interest in the purposes of art in general, in its ability to express mental and psychological states and in the expressive powers of different semiotic codes.

In conclusion, the empirical research described in this paper proposes the functional utilization of images, specifically painted pictures, in the teaching of literature in Secondary Education. It illustrates that paint images could have an interpretative value for literary texts, rather than serve a decorative purpose within the school books. The integration of art into literary education could enhance the students' interest in the ideas and the expressive means of literary texts and establish invigorating interdisciplinary links between literature and images. The promising findings of the empirical research presented in this paper could point towards the need of further research into the dialogic connection between literary texts and images and its fruitful application to the didactics of literature.

\section{References}

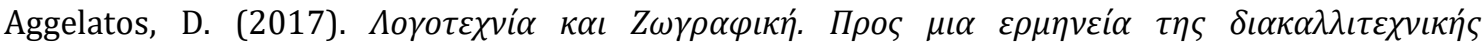
$(\alpha v \alpha) \pi \alpha \rho \alpha \dot{\sigma} \tau \alpha \sigma \eta \varsigma$ [Literature and Painting. Towards an interpretation of the interartistic (re)presentation]. Athens: Gutenberg.

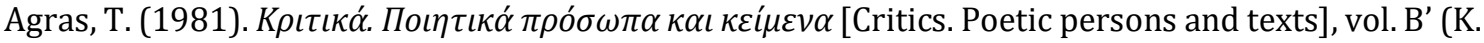
Stergiopoulos, ed.). Athens: Hermes.

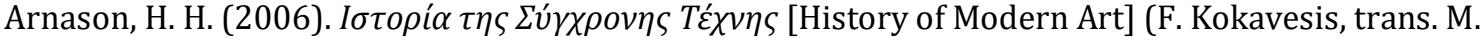
Papanikolaou, ed.). Thessaloniki: Epikentro.

Bakhtin, M. (1981). The Dialogic Imagination: Four Essays. (M. Holquist, ed. C. Emerson \&. M. Holquist, trans.). Austin: University of Texas Press.

Bakhtin, M. (1984). Esthétique de la création verbale. Paris: Gallimard.

Dabrowski, M. (1997). Egon Schiele: Master of Expressive Form. In Egon Schiele: The Leopold Collection, Vienna (pp. 8-31). New York: The Museum of Modern Art. Retrieved from:

https://www.moma.org/documents/moma catalogue 264 300063176.pdf

Egon Schiele: The Complete Works. Retrieved from: https://www.egon-schiele.net/biography.html

Faulkner, P. (2013). Modernism. London: Routledge.

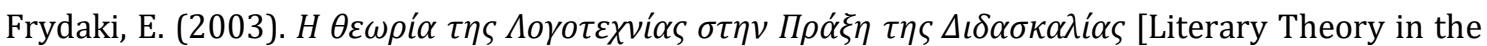
Act of Teaching]. Athens: Kritiki.

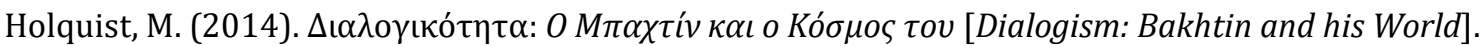
(I. Stamataki, trans.). Athens: Gutenberg.

Kalogirou, Tz. (2012). Light and Silence: Teaching approaches to Vermeer's Women through Painting and Poetry. In Proceedings of the I International Conference, Teaching Literature in English for 
Young Learners, 25-26 October 2012 (pp. 126-132). University of València, Facultat de Magisteri, Departament de Didàctica de la Llingua I la Literatura. València: Reproexprés.

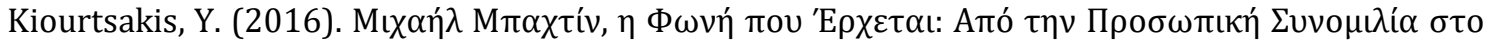

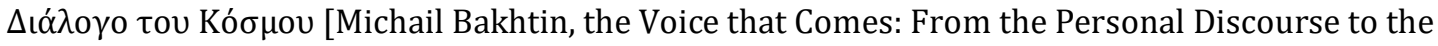

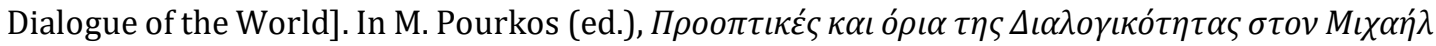

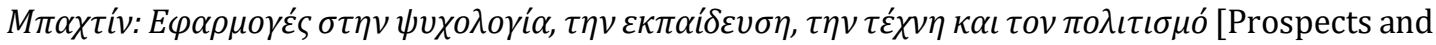
confines of Dialogism in Michail Bakhtin: Implementations in psychology, education, art and civilization] (pp. 111- 119). Patras: Opportuna.

Kostas Karyotakis. (2006). Battered Guitars: Poems and Prose. (W. W. Reader \& K. Taylor, trans.). University of Birmingham: Centre for Byzantine, Ottoman \& Modern Greek Studies.

Kristeva, J. (1969). Sèméiotikè - Recherches pour une sémanalyse. Paris: Éditions du Seuil.

Kristeva, J. (1980). Desire in Language: A Semiotic Approach to Literature and Art. New York: Columbia University Press.

Leopold, R. (1997). Introduction. In Egon Schiele: The Leopold Collection, Vienna (pp. 32-39). New York: The Museum of Modern Art. Retrieved from:

https://www.moma.org/documents/moma catalogue 264 300063176.pdf

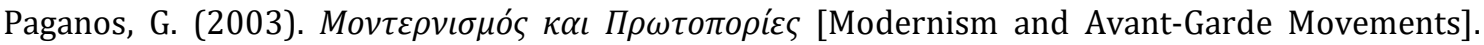
Athens: Savvalas.

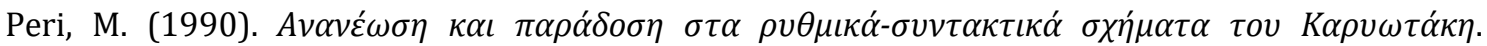
[Renewal and tradition in Karyotakis' rhythm- syntaxis.] In M. Melissaratou (ed.), Symposium for Karyotakis, 11-14 September 1986 (93-107). Preveza.

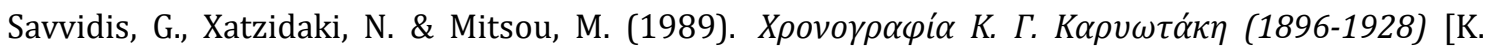
Karyotakis' Chronography]. Athens: M.I.E.T. (new edition, completed).

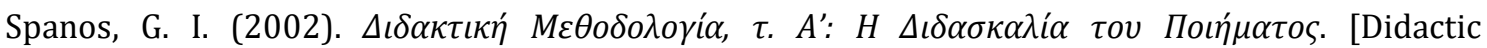
Methodology, v. A': The Teaching of the Poem]. Athens: Private Edition.

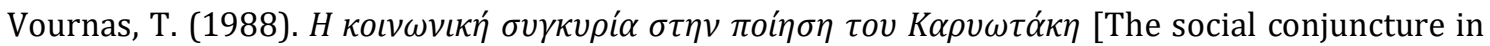
Karyotakis' poetry]. Journal $H \Lambda \varepsilon ́ \xi \eta$ [The Word], 8(79-80), 829-831.

Wertsch, J. \& Smolka, A. L. B. (1994). Continuing the dialogue. Vygotsky, Bakhtine and Lotman. In H. Daniels (ed.), Charting the Agenda: Educational Activity after Vygotsky (pp. 69-92). London: Routledge.

\section{How to cite this paper:}

Toutziaraki, M. (2019). The dialogic relationship between literary texts and paintings and its application to Literary Education in High School. Journal of Literary Education, (2), pp. 130-152. doi: 10.7203/JLE.2.13842 